\title{
Market orientation and new-to-the-world products: Exploring the moderating effects of innovativeness, competitive strength, and environmental forces
}

\author{
Mário Augusto ${ }^{1}$, Filipe Coelho* \\ University of Coimbra, School of Economics, Av. Dias da Silva, 165, 3004-512 Coimbra, Portugal
}

Received 5 May 2006; received in revised form 18 June 2007; accepted 26 September 2007

\begin{abstract}
Recently, there has been a keen research interest in exploring the relationship between market orientation and new product development. The empirical results, however, are mixed, and this means that we do not fully understand these linkages. Furthermore, research concerning the antecedents of new-to-the-world products has focused on the study of a single product. However, it is of obvious interest for organizations to understand what drives a firm's overall performance in the exercise of developing very innovative products. In this empirical study, the authors take a component-wise approach to investigate the effects of market orientation in new-to-the-world product innovation, and examine how other variables interplay with market orientation to affect product development. Firstly, the findings show that both customer and competitor orientations, together with interfunctional coordination, are important drivers of a firm's new-to-the-world product innovation. Secondly, the results indicate that the components of market orientation are differentially moderated by a firm's innovativeness, competitive strength, and also by environmental forces.
\end{abstract}

(C) 2007 Elsevier Inc. All rights reserved.

Keywords: New-to-the-world products; Market orientation; Innovativeness; Competitive strength; Environment

\section{Introduction}

The pursuit of a link between organizational culture and competitiveness has spurred research on the strategic orientation of firms, and in particular, the concept of market orientation has attracted a massive interest in the last decade. A number of researchers argue the possibility that market orientation contributes to organizational performance through the new products it helps bring to market (Deshpandé, Farley, \& Webster, 1993; Gatignon \& Xuereb, 1997). In fact, ensuring organizational prosperity can be considered the ultimate goal of new product development efforts ( $\mathrm{Li} \&$ Calantone, 1998; Wheelwright \& Clark, 1992). Therefore, of research interest for some time, has been whether market orientation affects product innovativeness, i.e., the degree of a product's newness.

\footnotetext{
* Corresponding author. Tel.: +351 239790574 .

E-mail addresses: maugusto@fe.uc.pt (M. Augusto), fcoelho@fe.uc.pt (F. Coelho).

${ }^{1}$ Tel.: +351 239790544 .
}

The links between market orientation and the degree of product innovation are far from being fully explained (Gatignon \& Xuereb, 1997; Lukas \& Ferrell, 2000; Zhou, Yim, \& Tse, 2005). The relationship between the three components of Narver's and Slater's (1990) conceptualization of market orientation and the development of innovative products, in particular, meets very mixed findings and arguments in the literature (e.g., Atuahene-Gima, 1996; Christensen \& Bower, 1996; Gatignon \& Xuereb, 1997; Lukas \& Ferrell, 2000; Slater \& Narver, 1994). Consequently, Zhou et al. (2005:43) have recently argued that "the central issue of whether market orientation facilitates or impedes breakthrough innovation remains unanswered". The disparate findings and contentions have led researchers to investigate how other organizational variables could possibly influence the effects of market orientation on new product innovativeness.

Thus, the goal of this article is to examine how market orientation interplays with other variables to influence the launch of new-to-the-world products, which are new to the company and new to the market. Products with a higher degree of innovation 
have a higher perceived sales and financial performance (Gatignon \& Xuereb, 1997; Zhou, 2006). Similarly, early entry has been associated with greater effectiveness of marketing mix strategies and greater market share (Szymanski, Troy, \& Bharadwaj, 1995), and also with higher firm survival rates (Robinson \& Min, 2002). Highly innovative products should thus contribute to a greater extent, to the overall performance of organizations.

Specifically, this research differentiates from other studies relating market orientation with product development, and thus contributes to existing theory and practice, by addressing a number of key gaps. Firstly, the focus of our study is on the factors contributing to an organization's performance in terms of new-tothe-world product innovation. In this way, we provide new insights, as the majority of past research investigating highly innovative products is concentrated on the drivers of a single innovation (e.g., Gatignon \& Xuereb, 1997; Zhou et al., 2005). It is of obvious interest for both practice and theory not just to understand the factors underlying product innovativeness, but also to appreciate those contributing to a firm's overall performance on this matter.

Secondly, we investigate how the three components of Narver's and Slater's (1990) conceptualization of market orientation influence the development and launch of new-tothe-world products, still an unresolved issue (Lukas \& Ferrell, 2000; Zhou et al., 2005).

Thirdly, we consider in our research when the expected effects of market orientation should take place, and this is important given the mixed results in extant literature concerning the relationship between market orientation and the development of highly innovative products. These mixed results suggest that the effects of market orientation may be contingent upon other variables, and this is consistent with previous studies (e.g., Baker \& Sinkula, 1999). Thus, we consider the moderating effects of a firm's innovativeness and competitive strength, on the relationship between market orientation and new-to-the-world product innovation. Several authors claim that the role of innovation has been neglected in market orientation studies (Jaworski \& Kohli, 1996; Hurley \& Hult, 1998). Furthermore, the interplay between market orientation and innovation is not yet well-understood (Han, Kim, \& Srivastava, 1998; Noble, Sinha, \& Kumar, 2002), and this will be particularly true in explaining product innovation. With regard to competitive strength, Burke (1984) found this to be a significant determinant of the strategic thrust of a strategic business unit. However, investigations on product development have failed to incorporate its potential effects. Furthermore, we investigate how environmental conditions moderate the effects of the market orientation components on the development of new-to-the-world products. Lukas and Ferrell (2000) conclude that new studies should explore how environmental forces interplay with market orientation to influence different types of product innovation. We expect that the moderating effects of firm innovativeness, competitive strength, and environmental forces will help explain some of the contradictory findings in the literature.

\section{Conceptual model and hypotheses}

New product development and market orientation. Innovation is the adoption of ideas concerning processes, products, systems, or devices, that is considered new by the adopting unit (Damanpour, Szabat, \& Evan, 1989; Garcia \& Calantone, 2002). Product innovation, in turn, is "new products or services introduced to meet an external user or market need" (Damanpour, 1991:561). The degree of product newness can either be measured from the firm or customer perspective. Following the taxonomy created by Booz, Allen, and Hamilton (1982), which is frequently used in marketing research (e.g., Lukas \& Ferrell, 2000; Olson, Walker, \& Ruekert, 1995), new products can be classified in four categories. New-to-the-worldproducts are new both to the market and the firm. At the other extreme, there are product modifications, which replace existing products with just a few changes, being therefore familiar to both the firm and the market. In between, there are line extensions and me-too products. Consequently, new-to-theworld products entail the largest degree of newness, and product modifications the lowest degree of newness, both to the firm and to the market.

In this work, our concern is with the determinants of products with a high degree of innovation, given their larger implications for firm performance. In particular, this study focuses on a firm's overall new-to-the-world product innovation which, consistent with the above conceptualizations, we define as a firm's introduction of new-to-the-world products in the marketplace.

We thus depart from the majority of past research investigating the determinants of highly innovative products, which has concentrated on a single product (e.g., Zhou et al., 2005). It seems logical to consider how market orientation, a general strategic orientation, affects the innovativeness of a firm's overall product development outputs. From a managerially and theoretical point of view, a major concern is the development of individual products, but also the range of products under development (Wheelwright \& Clark, 1992). Furthermore, it is quite plausible in theory that the true effects of market orientation can be more closely ascertained in relation to a general product innovation proficiency rather than to the characteristics of a particular product, the reason being that these are more likely to result from more idiosyncratic influences, and this may, to some extent, obscure the role of such a strategic orientation. Considering that the risk associated with the development of highly innovative products is a force that drives companies to invest in less innovative products, our research goal is in line with claims that firms must build the organizational structure that supports the need for having a larger number of breakthrough projects in their portfolio of new products under development (Wind \& Mahajan, 1997).

Evidence of the role of market orientation in fuelling new products with a high degree of innovation is mixed. Drawing upon previous research, Narver and Slater (1990:21) defined market orientation as the organizational culture "that most effectively and efficiently creates the necessary behaviors for the creation of superior value for buyers and, thus, continuous superior performance for the business". Narver and Slater consider that market orientation embraces three components: customer orientation, competitor orientation, and interfunctional coordination. Customer and competitor orientation concerns the 
activities involved in the collection of information about buyers and competitors and in its dissemination throughout the firm. Interfunctional coordination involves the coordination of efforts organization-wide to create superior value for buyers, based on the information acquired about customers and competitors.

A significant number of studies claim that a market-oriented culture and behavior generate superior product innovation and new product performance (e.g., Deshpandé et al., 1993; Kohli \& Jaworski, 1990; Slater \& Narver, 1994). However, some argue that the adoption of the marketing concept fosters imitations and restrains the development of breakthrough innovations (Bennett \& Cooper, 1981; Christensen \& Bower, 1996; Voss \& Voss, 2000). Consequently, we still do not understand very well, the links between the components of market orientation and product innovation. Following previous research (e.g., Noble et al., 2002; Shamsie, Phelps, \& Kuperman, 2004; Zhou, 2006), we consider how other organizational factors, namely firm innovativeness and competitive strength, and also environmental forces, might interplay with the market orientation components to affect a firm's product innovation.

Firm innovativeness can be seen as an organization's inclination to "engage in innovative behavior" (Auh \& Menguc, 2005:250). Hurley and Hult (1998) consider it a measure of an organization's orientation towards innovation. This is a facet of organizational culture that reflects the extent to which the firm is open to new ideas, accepts and stimulates novel approaches to market needs, stimulates ideas that challenge current practices and assumptions, fosters risk-taking and a proactive attitude. Therefore, the degree of innovativeness is likely to determine when market information results in innovative or incremental products, and this suggests a moderating role for firm innovativeness. This perspective differs from some previous studies, which have considered firm innovativeness as a mediator of the market orientation effects. However, the findings of such studies have been mixed (e.g., Hult, Hurley, \& Knight, 2004; Noble et al., 2002).

The marketing literature has been lately emphasizing the fact that market orientation should be conceived hand in hand with an innovation strategy (Han et al., 1998; Hult \& Ketchen, 2001) or an entrepreneurial spirit (Baker \& Sinkula, 1999; Slater \& Narver, 1995). Han et al. (1998:41), for example, argue that "formulating an innovation strategy to complement the firm's market orientation strategy should provide a more coherent and comprehensive road map for organizations to follow". This suggests that innovativeness can be considered another orientation side by side with market orientation, and this conforms with Hult and Ketchen (2001). In fact, just because a firm is market-oriented, does not necessarily imply that it will be more innovative. Evidence from several organizations points in this direction. Motorola and Yahoo! are two major organizations that are certainly oriented towards customers' needs, and that are also concerned with competitors. However, it seems that the extent to which their concern with customers and, more broadly, the market information they have, is linked with organizational performance, is contingent upon each firm's degree of innovativeness. The failure of the ambitious Iridium project in 1998 affected Motorola's confidence. The appoint- ment of a new chief in early 2004, however, was instrumental in building an atmosphere of risk-taking and innovation which now seems to be paying off, with Motorola regaining lost ground with the launch of innovative mobile handsets that competitors have been emulating (Anonymous, 2006a). Yahoo! seems to be slow, cumbersome, and more risk averse, and this may help to explain why the firm is lagging behind in online advertising sales and in market value (Anonymous, 2006b).

In summary, this evidence points to innovativeness as a distinct fact of organizational life that may or may not co-exist with a market orientation. Furthermore, it suggests that the effects of a market orientation when the firm has a higher innovativeness will be different from those when the company is less innovative. This evidence might also explain the mixed findings concerning the mediating role of firm innovativeness.

According to Burke (1984:347), competitive strength "is an indication of the business unit's advantages or position in the market vis-a-vis major competitors and its ability to compete". Competitive strength "captures the importance of competitors and customers in determining that position" (p. 346), and thus, it has an apparent explanatory power over performance. However, studies on new product development, namely those investigating the linkages between market orientation and product innovation, have not considered its potential explanatory power. We thus consider its moderating effects. Hult and Ketchen (2001) consider that the distinguishing feature of market orientation "is system-wide attention to markets" (p. 901) and that this is not enough to build a 'positional advantage' or to make a firm uniquely competitive. Dickson (1992), for example, argues that firms have differential implementation abilities, which are crucial for competitive advantage: "Companies that are very good at implementing (getting things done) have an inherent competitive advantage. They are able to change and adapt faster than other companies" (p. 71). Dickson also points out that firms with more resources, with a larger market share, or that move more quickly, can have a higher impact on market dynamics. Competitive strength captures the way the firm systematically moves around in its environment, and the extent to which it stands out from the crowd. Consequently, and regardless of the market orientation or even of innovativeness levels, competitive strength can be an important factor determining when market orientation leads to the introduction of innovative products in the market.

Finally, several studies have reported that the environment moderates the success of new product introduction and the effectiveness of different strategic choices or orientations associated with new product development (Gatignon \& Xuereb, 1997; Li \& Calantone, 1998; Lukas \& Ferrell, 2000; Zhou, 2006). Following contingency theory, the effectiveness of strategies is not universal to organizations and environmental conditions. Consequently, strategic decisions must consider and be adapted to the environment (Ginsberg \& Venkatraman, 1985). Technological turbulence and competitive intensity have been frequently considered in new product development studies (e.g., Gatignon \& Xuereb, 1997; Li \& Calantone, 1998; Zhou, 2006) and, therefore, we explore their effects. Technological turbulence is the extent to which the industry is characterized by 
rapidly changing technologies (Kohli \& Jaworski, 1990), whereas competitive intensity is the extent to which companies face competition over the output market resources they need to live and grow (Achrol \& Stern, 1988; Aldrich, 1979). Consistent with previous research (e.g., Atuahene-Gima, Li, \& De Luca, 2006; Han et al., 1998), we only predict moderating effects for these environmental forces. The conceptual framework that guides our research is depicted in Fig. 1.

\subsection{Market orientation and new-to-the-world product innovation}

Following past studies (e.g., Gatignon \& Xuereb, 1997; Han et al., 1998; Li \& Calantone, 1998; Lukas \& Ferrell, 2000; Noble et al., 2002), we take a component-wise approach in the investigation of the links between market orientation and product development. That is, we disentangle the effects of the market orientation components on new-to-the-world product innovation. Li and Calantone (1998) consider that each component has its own locus of interest and that each involves different cognitive activities. We first develop the hypotheses concerning the main effects. In the presence of moderating effects, the main effects should be interpreted as the predictor effects at the average level of the moderating variables.

\subsubsection{Customer orientation}

A number of authors argue that an over-reliance on customer feedback impacts negatively on the degree of product innovation (Bennett \& Cooper, 1981; Christensen, 1997; Christensen \& Bower, 1996). Christensen and Bower (1996:198), for example, contend that many large organizations fail because "they listen too carefully to their customers - and customers place stringent limits on the strategies firms can and cannot pursue". Underlying this claim is the idea that frequently, customers do not know how their needs will evolve and how certain technologies may impact on the satisfaction of their needs. Therefore, it is reasoned that managers, based on customers' feedback, are forced into developing new products that are similar to existing ones.

The idea that customer orientation may impact negatively on product innovation derives, partially, from a too-narrow understanding and implementation of what a customer orientation means. In fact, it has been recognized by many authors (e.g., Han et al., 1998; Kohli \& Jaworski, 1990; Narver \& Slater, 1990; Slater \& Narver, 1998, 1999) that being customer-oriented goes far beyond simply listening to customers. It also involves an understanding of how the future needs of customers will evolve and of how the organization can satisfy them. In this context, we propose the following:

H1. Customer orientation has a positive effect on new-to-theworld product innovation.

\subsubsection{Competitor orientation}

It has been argued that too much focus on competitors is likely to obscure opportunities for differentiation, and to deflect attention from changes in market segment structures and customer needs, thus reducing the development of innovative strategies and leading to the emulation of competitors' strategies (Day \& Wensley, 1988). In a product setting, this would imply that a too-strong competitor focus would preclude the development of breakthrough products, leading instead to the development of me-too-products. Other authors (e.g., Bennett \& Cooper, 1981; Hayes \& Abernathy, 1980) also concur with this argument, asserting that concern with competitors' activities presents imitation as an attractive source of product innovation, as it minimizes risks, and development and launching costs. In this context, Lukas and Ferrell (2000) observed that a competitor orientation was negatively related with the development of new-to-the-world products.

However, and following Narver and Slater (1990:21), we consider that competitor orientation comprises the analysis of current and potential competitors, and this includes "the total set of technologies capable of satisfying" present and future customers'

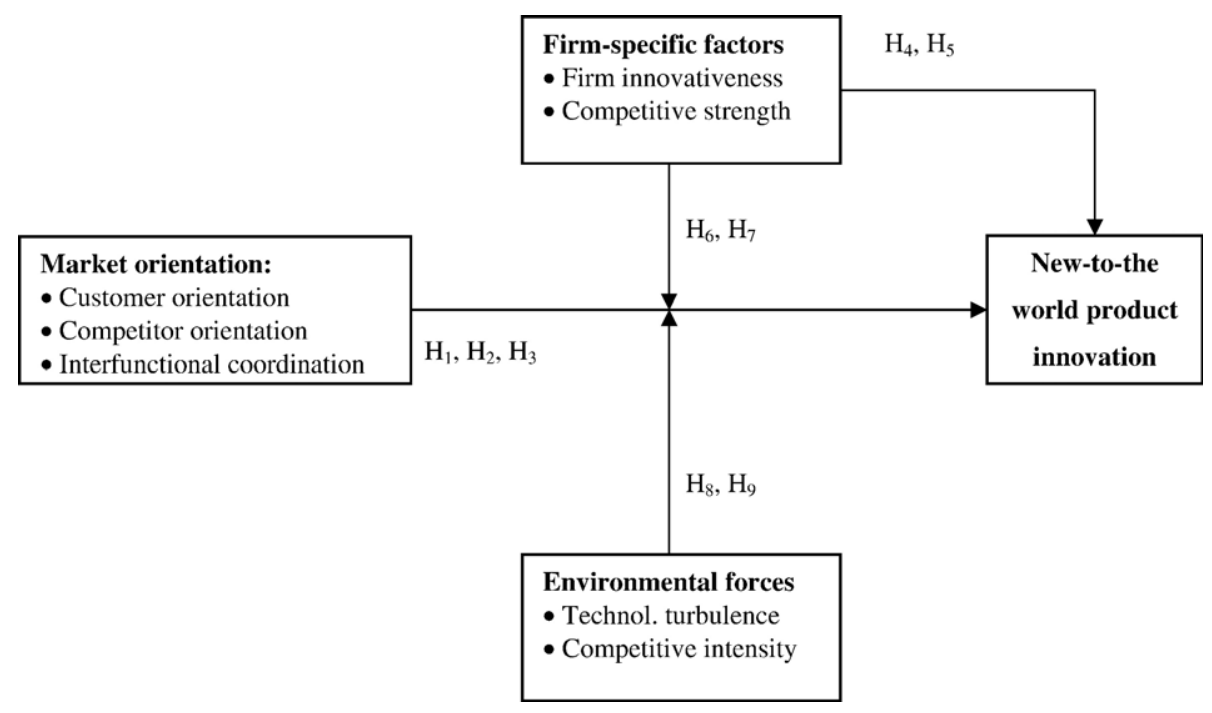

Fig. 1. A conceptual framework of market orientation, innovativeness, competitive strength, environmental forces, and new-to-the-world product innovation. 
needs. In this sense, scanning competitors can help an organization to identify emerging substitutes, the speed with which substitute technologies will disseminate, and the timing of technological shifts (Zahra, Nash, \& Brickford, 1995). Zahra and colleagues note that this information can be incorporated into planning $R \& D$, in determining the timing of market entry, and selecting an appropriate positioning for an organization's technologies, concluding that even though technological forecasting "cannot guarantee the continued success of the pioneer, it does assist in predicting possible paths of technological change and the technological implications" (p. 24). Furthermore, without competitor knowledge, managers cannot identify the best courses of action to protect or enhance their current position (Day \& Wensley, 1988). Given the mixed evidence, we predict the following:

H2. Competitor orientation has a positive effect on new-to-theworld product innovation.

\subsubsection{Interfunctional coordination}

Following Narver and Slater (1990), interfunctional coordination entails the collaboration of different functional units that put aside functional interests in the pursuit of organizational goals. The process of interfunctional coordination fosters communication, collaboration, cohesiveness, trust, and commitment between different functional areas (Auh \& Menguc, 2005), and this is claimed to promote the extent of product innovation (Gatignon \& Xuereb, 1997). Indeed, integration fosters the amount of ideas, facilitates their internal dispersion, and this also spurs their cross-fertilization (Aiken \& Hage, 1971; Zahra et al., 1995).

Additionally, selling a new technology requires interfunctional collaboration to solve technical and market issues and to achieve speed (Zahra et al., 1995). Li and Calantone (1998:16) state that a firm with a better interface between marketing and $\mathrm{R} \& \mathrm{D}$ "is able to realize its technological capability more efficiently than its competition by identifying innovative product features desired by the market", enhancing new product advantage. In fact, several studies have corroborated the link between coordination and innovation (see Damanpour, 1991).

However, the results obtained in other studies do not lend much support for a positive link. Lukas and Ferrell (2000) observed that coordination was not related to the development of new-to-theworld products, and Gatignon and Xuereb (1997) observed a limited role for it. Lukas and Ferrell advanced the possibility that as the number of units involved increases, the level of organizational stress is also likely to increase, and that one way of overcoming such is to avoid unfamiliar, more innovative, projects. Another reason is that because interfunctional coordination involves the accommodation of disparate views (Auh \& Menguc, 2005), very innovative ideas may lose their 'innovation' in consequence of the compromises that are undertaken under the coordination efforts. Auh and Menguc add that interfunctional coordination may backfire by homogenizing the pool of talents, limiting innovativeness. Despite this last evidence, we offer the following:

H3. Interfunctional coordination has a positive effect on newto-the-world product innovation.

\subsection{Firm innovativeness}

A firm oriented towards innovation values change, and encourages risk-taking and creativity, making employees feel less threatened when risking efforts into new areas. Thus, managers are more likely to be open-minded and think outside the box, generating breakthrough rather than incremental concepts (Zahra et al., 1995). Damanpour (1991), in a metaanalysis, concludes that attitude towards change is systematically related to the introduction of innovations. Hurley and Hult (1998) also observe that innovativeness contributes to a firm's capacity to innovate, that is, to implement new ideas, processes or products. Based on this evidence, we suggest:

H4. Firm innovativeness has a positive effect on new-to-theworld product innovation.

\subsection{Competitive strength}

According to the resource-based view (Barney, 1991), firms that are highly competitive base their advantages on resources and skills that are difficult to replicate, and seek to anticipate the resources and skills that fit expected changes in technologies, consumers, regulations, competition and social values. Consequently, they will be among the first to identify trends in consumers' needs and to take advantage of new technologies to promptly satisfy value creation opportunities. Furthermore, highly competitive firms continuously scrutinize their environment, not only to anticipate but also to shape the evolution of the markets in which they play. This implies that these companies are likely to seek and benefit from first-mover advantages in launching truly innovative products.

Hence, these companies "fundamentally change the game in ways that disadvantage incumbents - devising novel approaches to market entry, advantage building and competitive warfare ... the goal is not competitive imitation but competitive innovation" (Hamel \& Prahalad, 1995:37-38). Therefore, we propose the following:

H5. Competitive strength has a positive effect on new-to-theworld product innovation.

\subsection{Moderating effects}

\subsubsection{Market orientation and firm innovativeness}

Menon and Varadarajan (1992) contend that cultures supporting innovation foster the sharing and utilization of information. Therefore, customer and competitor knowledge is likely to yield greater product innovation when a firm has an innovation-oriented outlook. The argument is that managers are more likely to use this information in more creative ways, thus yielding greater product innovativeness. The effects of coordination should also be strengthened, as the negative effects that may be associated with coordination, including stress, resistance to major changes, and the accommodation of different points of view, are likely to be lower when there is an 
organization-wide openness to new ideas and practices. Consequently, we propose the following:

H6a. Firm innovativeness strengthens the positive effects of customer orientation on new-to-the-world product innovation.

H6b. Firm innovativeness strengthens the positive effects of competitor orientation on new-to-the-world product innovation.

H6c. Firm innovativeness strengthens the positive effects of interfunctional coordination on new-to-the-world product innovation.

\subsubsection{Market orientation and competitive strength}

Because of the nature of their resources and capabilities, and also their strategic marketing positioning, highly competitive firms are more likely to take advantage of the market intelligence they gather, and this should spur their innovation activity. Furthermore, the effects of coordination should be strengthened. Organizations with such a market positioning are more likely to use interfunctional coordination to solve technical issues and accelerate the product development process, thus enhancing their ability to be the first in the market with new products. We therefore propose the following:

H7a. Competitive strength enhances the positive effects of customer orientation on new-to-the-world product innovation.

H7b. Competitive strength enhances the positive effects of competitor orientation on new-to-the-world product innovation.

H7c. Competitive strength enhances the positive effects of interfunctional coordination on new-to-the-world product innovation.

\subsubsection{Market orientation and technological turbulence}

Kohli and Jaworski (1990) argue that in these turbulent environments, being customer-focused is less important because many innovations are developed by R\&D personnel who frequently work outside the industry where it disseminates. Jaworski and Kohli (1993) add that through technological innovation, firms may develop competitive innovations, lessening the link between market orientation and performance. Notwithstanding, Day and Wensley (1988) argue that in such environments, customer interaction provides a direction for product development efforts. Narver and Slater (1990) also note that these environments provide more opportunities for creating value to customers, and this would pave the way for the introduction of innovative products. The link between competitor orientation and product innovation is also likely to be intensified in these environments because competitor intelligence will provide warnings about whether competition can use opportunities created by an emerging technology to improve new product development (Li \& Calantone, 1998).

Technological turbulence is a source of uncertainty (Pfeffer \& Salancik, 1978), as it makes it more difficult to specify in advance the technologies that will prevail and the timing of technological shifts. This type of uncertainty can paralyze strategic planning because decision-makers will spend more time discussing how the environment will evolve, assessing the impact on the organization, and developing different courses of action. Anderson, Day, and Rangan (1997:63) state that in fast changing environments, "there is no time for exhaustive forecasting and analysis, and it is difficult to pin down means-ends relationships and forecast outcomes". In technologically-turbulent environments, rapid decision-making seems to be a necessity. As coordination is a time consuming process, we expect technological turbulence to have a detrimental effect on the relationship between coordination and new-to-the-world product innovation. Therefore, we offer the following:

H8a. Technological turbulence enhances the positive effects of customer orientation on new-to-the-world product innovation.

H8b. Technological turbulence enhances the positive effects of competitor orientation on new-to-the-world product innovation.

H8c. Technological turbulence weakens the positive effects of interfunctional coordination on new-to-the-world product innovation.

\subsubsection{Market orientation and competitive intensity}

In competitive environments consumers can choose from a wider pool of offers in the market. Consequently, monitoring customers' needs becomes more important to ensure that customers do not select competing alternatives (Kohli \& Jaworski, 1990). A stronger focus on competitors is likely to be required, as this helps in identifying what customers want, and in anticipating changes in competitors' product strategies. With regard to coordination, competitive intensity is likely to mitigate its relationship with product innovation, the reason being that competitive environments require fast decisionmaking, and coordination, and because of its consensus decision style, it is likely to hinder responses to competitive developments. We therefore propose the following:

H9a. Competitive intensity enhances the positive effects of customer orientation on new-to-the-world product innovation.

H9b. Competitive intensity enhances the positive effects of competitor orientation on new-to-the-world product innovation.

H9c. Competitive intensity weakens the positive effects of interfunctional coordination on new-to-the-world product innovation.

\section{Research methodology}

\subsection{Sample selection and data collection}

The setting for the study is the Portuguese economy, which has a small internal market and relatively small firms. It is, however, a very open economy. Consistent with previous research (e.g., Gatignon \& Xuereb, 1997; Zhou, 2006), the authors used as a sample frame, a commercial list of the largest 500 Portuguese companies. To guarantee the reliability of information, only those companies that have provided income and balance sheets could be included in the ranking. Additionally, this list excludes financial 
services and holdings. The ranking was based on firm sales, and includes a diversity of industries, such as chemicals, agriculture, pulp and paper, telecommunications, food distribution, and hotels. This diversity contributes to the generalization of findings. The companies on this sample frame had an annual average sales volume of approximately $€ 151$ million, but $70 \%$ of the firms had sales only up to $€ 100$ million. The average number of employees is 555 , but the majority of firms $(75.8 \%)$ have up to 500 employees.

Of the 500 self-administered questionnaires that were mailed, 16 were returned as 'undeliverable'. This mail survey was followed by phone calls to stimulate the response rate. We received 101 filled questionnaires, which, because of incomplete data resulted in 89 questionnaires for analysis. This yielded a net response rate of $18.4 \%$, which compares favorably with other studies (e.g., Atuahene-Gima \& Evangelista, 2000; Gatignon \& Robertson, 1989; Gatignon \& Xuereb, 1997). The questionnaires were sent to marketing directors, who have been shown to be key informants concerning new product development (Gatignon \& Xuereb, 1997; Han et al., 1998). The respondents typically hold marketing responsibilities, but there were also many respondents with business development and board level responsibilities. Regarding firm size, the responding firms closely match the sample frame in terms of number of employees. In respect of sales breakdown, of the 85 firms responding, $54.7 \%$ obtained $95 \%$ or more of their sales from goods, whereas $38.4 \%$ obtained at least $95 \%$ of sales from services. No systematic differences were found between early and late respondents.

\subsection{Measures}

For collecting the data we relied on a structured questionnaire. The constructs' measures were derived from existing literature. For measuring each of the market orientation components we considered the market orientation scale developed by Narver and Slater (1990), since that has been widely adopted. Firm innovativeness was measured with three items taken from Hult, Ketchen, and Nichols (2002). The measures for technological turbulence, and competitive intensity were taken from Jaworski and Kohli (1993). These scales were measured on a seven-point scale (1-strongly disagree, 7 -strongly agree). The measure for competitive strength is derived from Burke (1984), and asked managers how they rated the organization against competitors on five items. This scale was also measured on a seven-point Likert scale $(1-$ much lower, 7-much higher).

Finally, we considered two items for measuring the firm's new-to-the-world product innovation. Lukas and Ferrell (2000) assessed the extent of product innovation by simply asking the number of products each SBU introduced in the market in the past three years for each category of product innovation. For new-to-the-world products they provided the description "number of new-to-the-world products (products new to your organization and new to your market)". In the belief that product innovation can be more appropriately described on a continuum, and with a multi-item scale, we asked managers to indicate, relative to competitors and to the last two years, how they rated on a seven-point scale (1-poor, 7-excellent) the "number of completely new products (products new to your company and new to your market) launched in the market", as well as the "degree of innovativeness of the products launched in the market". Details of the scale's items are presented in the Appendix A.

\subsection{Measurement analysis}

To examine and ensure the psychometric properties of the scales used in this study, the measures were submitted to a number of procedures. Firstly, we conducted preliminary data analysis, including item-to-total correlations and exploratory factor analysis for each scale, to identify ill-fitting items and uni-dimensionality. Each scale's items were then subject to onefactor confirmatory analysis, which further indicated the unidimensionality of each scale. Given the limited sample size, and also in an attempt to test construct convergence within maximally-similar sets of constructs, we subsequently divided the variables into three related groups for further construct validity examination with confirmatory factor analysis (CFA) (for a similar strategy see Baker \& Sinkula, 1999; Hult et al., 2004): the three components of market orientation, the two environmental factors, and a third group that contained firm innovativeness, competitive strength, and new-to-the-world product innovation.

Considering the market orientation components, the threefactor CFA indicates that the hypothesized model does not fit the data well (Goodness of Fit Index $[\mathrm{GFI}]=.82$; TuckerLewis Index $[\mathrm{TLI}]=.83$; Comparative Fit Index $[\mathrm{CFI}]=.87$; Root Mean Square Error of Approximation [RMSEA] =.12). Improvement of the model could be obtained by eliminating some items, but this would lead to scales with only a few items, thereby limiting their capacity to capture the domain of the respective constructs. In some previous research using the conceptualization of Market Orientation by Narver and Slater there were also measurement issues. Narver and Slater (1990), for example, found a strong correlation between the three market orientation components, and also obtained a onefactor solution in exploratory factor analysis for the items of the three components, and thus ended aggregating these components. Given this background, it seems in this case acceptable to introduce correlated errors, and we have subsequently introduced four. The resulting fit statistics are as follows: $\chi^{2}=92.91, d f=58, p=.002 ; \mathrm{GFI}=.88$; TLI $=.93$; $\mathrm{CFI}=.95$; $\mathrm{RMSEA}=.08$. All items have loadings in the appropriate latent construct that are highly statistically significant, thereby demonstrating convergent validity. The magnitude of the corresponding residuals and modification indices is low, thus providing further evidence of unidimensionality. The composite reliability exceeds in all cases the .7 level, thus indicating a high degree of internal consistency. The average variances extracted exceed the common .5 cut off, except for interfunctional coordination. However, some authors (e.g., Hatcher, 1994) consider that minimum to be conservative. 
Table 1

Descriptive statistics, correlation matrix, reliability, and variance extracted estimates

\begin{tabular}{|c|c|c|c|c|c|c|c|c|c|c|c|c|}
\hline & Mean & $\mathrm{SD}$ & $X_{1}$ & $X_{2}$ & $X_{3}$ & $X_{4}$ & $X_{5}$ & $X_{6}$ & $X_{7}$ & $X_{8}$ & $\mathrm{CR}$ & AVE \\
\hline Customer orientation $\left(X_{1}\right)$ & 5.54 & 1.01 & - & & & & & & & & .86 & .56 \\
\hline Competitor Orientation $\left(X_{2}\right)$ & 4.98 & 1.17 & .58 & - & & & & & & & .83 & .56 \\
\hline Interfunctional coordination $\left(X_{3}\right)$ & 4.56 & 1.20 & .51 & .62 & - & & & & & & .77 & .46 \\
\hline Innovativeness $\left(X_{4}\right)$ & 4.76 & 1.06 & .50 & .37 & .54 & - & & & & & .79 & .56 \\
\hline Competitive strength $\left(X_{5}\right)$ & 5.14 & .88 & .45 & .53 & .34 & .41 & - & & & & .81 & .46 \\
\hline Competitive intensity $\left(X_{6}\right)$ & 5.04 & 1.19 & .27 & .31 & .12 & -.13 & .08 & - & & & .71 & .38 \\
\hline Technological turbulence $\left(X_{7}\right)$ & 4.54 & 1.18 & .08 & -.05 & -.14 & -.01 & .14 & -.17 & - & & .82 & .54 \\
\hline New-to-the-world product innovation $\left(X_{8}\right)$ & 4.67 & 1.36 & .38 & .34 & .20 & .25 & .26 & -.05 & .38 & - & .81 & .69 \\
\hline
\end{tabular}

Notes: $\mathrm{CR}=$ Composite Reliability; AVE $=$ Average Variance Extracted.

The two environmental factors are also represented satisfactorily by a two-factor CFA $\left(\chi^{2}=31.84, d f=19, p=.03\right.$; $\mathrm{GFI}=.91 ; \mathrm{TLI}=.90 ; \mathrm{CFI}=.93$; $\mathrm{RMSEA}=.09)$. The items had statistically significant loadings, indicating convergent validity. The composite reliability of the two constructs also meets the .7 level. Of these two constructs, only competitive intensity has an average variance extracted below .5 .

The three-factor CFA for the last set of variables, firm innovativeness, competitive strength, and new product innovation, also fits the data satisfactorily $\left(\chi^{2}=44.06, d f=32, p=.08\right.$; $\mathrm{GFI}=.91 ; \mathrm{TLI}=.94 ; \mathrm{CFI}=.96$; $\mathrm{RMSEA}=.07)$. The composite reliability of the three constructs meets the .7 threshold. The convergent validity of each of these scales was indicated by the large standardized loadings that were all highly significant $(p<.01)$. The average variances extracted meet the .5 threshold, except for competitive strength. In summary, the measurement scales tend to meet the accepted standards for internal consistency and convergent validity. As to discriminant validity, all of the construct inter-correlations are significantly different from 1 , and the squared correlation between any two constructs is less than the respective average variances extracted (Fornell \& Larcker, 1981). Table 1 reports univariate statistics, zero- order correlation coefficients, composite reliabilities, and average variances extracted for the measurement scales.

\section{Results}

Model estimation was conducted using hierarchical multiple regression. Prior to model estimation, however, we meancentered the independent variables to reduce the multicolinearity resulting from the presence of multiplicative terms in the model (Aiken \& West, 1991). A step-down approach, which Aiken and West (1991) recommended for exploratory studies with higher order terms, was adopted. Hence, model estimation began with the full model, and step-by-step, the non-significant interaction terms were removed. The latter's effect is to increase the standard errors of the regression coefficients, which makes it more difficult for the significant true effects to emerge (Aiken \& West, 1991:103), and this will be particularly evident with smaller samples. This model estimation approach also complies with the parsimony principle, according to which, higher order terms should be introduced only if they significantly improve explanation beyond that provided by their lower order terms (Aiken \& West, 1991; Kleinbaum, 1994; Tate, 1984).

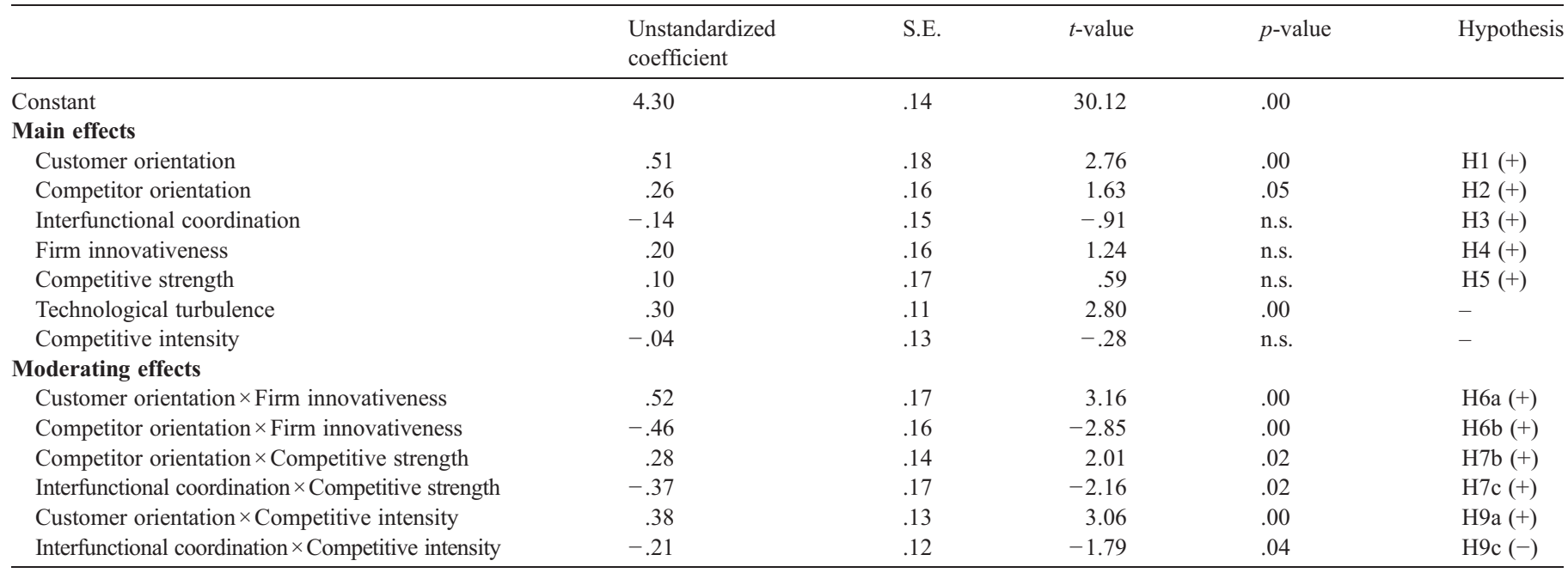

Note: Tests of hypotheses are one-tail tests. 
The results of the final model, which comprise all main effects and the significant interactions, are presented in Table 2. The largest variance inflation factor is 3.2 , and the largest condition index is 5.6. These values are well below the threshold of 10 and 30, respectively (Hair, Anderson, Tatham, \& Black, 1998), thus indicating no major problems of multicolinearity. The White's test for heteroscedasticity was not significant $(p>.10)$, and the residuals were normal. Finally, the estimated model explains a significant amount of variance $\left(F=4.81, p<.000 ; R^{2}=45.5 \%\right.$; adjusted $R^{2}=36 \%$ ), comparing quite favorably with other studies (e.g., Atuahene-Gima et al., 2006; Gatignon \& Xuereb, 1997; Lukas \& Ferrell, 2000). Also noteworthy is that the inclusion of the moderating effects increases the $R^{2}$ by $13.4 \%$, and this is statistically significant $(p=.01)$.

Hypothesis 1 predicted that customer orientation was positively related with new-to-the-world product innovation, and the results support this prediction $(b=.51 ; p=.00)$. Competitor orientation exhibits a significant positive association with product innovation $(b=.26 ; p=.05)$, thus supporting Hypothesis 2. Hypothesis 3 predicted a positive relationship between interfunctional coordination and product innovation, but is not supported $(b=-.14 ; p>.10)$.

Firm innovativeness also has no direct effect on new-to-theworld product innovation $(b=.20 ; p>.10)$, thus not supporting Hypothesis 4. Similarly, the results fail to support Hypothesis 5, which predicted a positive relationship between competitive strength and new-to-the-world product innovation $(b=.10 ; p>.10)$.

Hypothesis $6 \mathrm{a}$ predicted that firm innovativeness would strengthen the effects of customer orientation. Table 2 reveals a significant interaction effect in the hypothesized direction $(b=.52 ; p=.00)$. Hypothesis $6 \mathrm{~b}$ also predicted that innovativeness would enhance the effects of competitor orientation but we obtained a significant negative effect, indicating instead an attenuation of the relationship $(b=-.46 ; p=.00)$. We also predicted that firm innovativeness would enhance the positive effects of interfunctional coordination, but no significant interaction effect emerged $(p>.10)$.

Competitive strength moderates the effects of some of the market orientation components. According to Hypothesis 7a, competitive strength should enhance the effects of customer orientation, but the results failed to support this prediction $(p>.10)$. We also predicted in Hypothesis $7 \mathrm{~b}$ that competitive strength would enhance the effects of competitor orientation, and this was supported $(b=.28 ; p=.02)$. Hypothesis $7 \mathrm{c}$ posited that competitive strength would enhance the effects of interfunctional coordination. We obtained a significant negative interaction coefficient $(b=-.37 ; p=.02)$, thereby contradicting Hypothesis 7c.

Hypotheses $8 \mathrm{a}$ and $8 \mathrm{~b}$ predicted that technological turbulence would enhance the effects of customer and competitor orientation, respectively, and $8 \mathrm{c}$ considered that technological turbulence would attenuate the effects of interfunctional coordination. None of these hypotheses received support $(p>.10)$. However, technological turbulence was detected to exert a positive main effect on product innovation, and this was unexpected $(b=.30 ; p=.00)$.
Finally, the results indicate that competitive intensity enhances the positive relationship between customer orientation and new-to-the-world product innovation $(b=.38 ; p=.00)$, and this supports Hypothesis 9a. Hypothesis 9b predicted that the effects of competitor orientation would be enhanced in highly competitive environments, but the results failed to support it $(p>.10)$. The estimated model also reveals that competitive intensity decreases the effect of interfunctional coordination on product innovation $(b=-.21 ; p=.04)$, and this conforms to Hypothesis 9c. Table 3 summarizes the results of hypotheses testing.

We have run two additional regression models to more precisely identify the role of the proposed moderating variables. Considering the procedure suggested by Sharma, Durand, and Gur-Arie (1981), we have initially developed a model with just the three market orientation components. Consistent with the overall model that we develop and test, only customer and competitor orientation were significantly associated with newto-the-world product innovation. Subsequently, we ran an additional model now also including firm innovativeness,

Table 3

Summary of hypotheses testing

\begin{tabular}{llll}
\hline & Hypothesis & Coefficient & Result \\
\hline Main effects & & & \\
Customer orientation & $\mathrm{H} 1(+)$ & + & Supported \\
Competitor orientation & $\mathrm{H} 2(+)$ & + & Supported \\
Interfunctional coordination & $\mathrm{H} 3(+)$ & $\mathrm{Ns}$ & Unsupported \\
Firm innovativeness & $\mathrm{H} 4(+)$ & $\mathrm{Ns}$ & Unsupported \\
Competitive strength & $\mathrm{H} 5(+)$ & $\mathrm{Ns}$ & Unsupported \\
Technological turbulence & - & + & Unpredicted \\
Competitive intensity & - & $\mathrm{Ns}$ & Unpredicted
\end{tabular}

Moderating effects

Customer orientation $x$

Firm innovativeness

Competitor orientation $x$

Firm innovativeness

Interfunctional coordination $\times$

Firm innovativeness

Customer orientation $x$

Competitive strength

Competitor orientation $\times$

Competitive strength

Interfunctional coordination $\times$

Competitive strength

Customer orientation $\times$

Technological turbulence

Competitor orientation $\times$

Technological turbulence

Interfunctional coordination $\times$

Technological turbulence

Customer orientation $x$

Competitive intensity

Competitor orientation $x$

Competitive intensity

Interfunctional coordination $\times$

Competitive intensity

$\begin{array}{lll}\text { H6a (+) } & + & \text { Supported } \\ \text { H6b (+) } & - & \text { Unsupported } \\ \text { H6c (+) } & \text { Ns } & \text { Unsupported } \\ \text { H7a (+) } & \text { Ns } & \text { Unsupported } \\ \text { H7b (+) } & + & \text { Supported } \\ \text { H7c (+) } & - & \text { Unsupported } \\ \text { H8a (+) } & \text { Ns } & \text { Unsupported } \\ \text { H8b (+) } & \text { Ns } & \text { Unsupported } \\ \text { H8c (-) } & \text { Ns } & \text { Unsupported } \\ \text { H9a (+) } & + & \text { Supported } \\ \text { H9b (+) } & \text { Ns } & \text { Unsupported } \\ \text { H9c (-) } & - & \text { Supported } \\ & & \end{array}$

Note: The direction of the relationship between the predictors and the predicted variable is given by the signs $(+)$ and $(-)$; Ns - means the coefficient is not significantly different from zero. 
a)

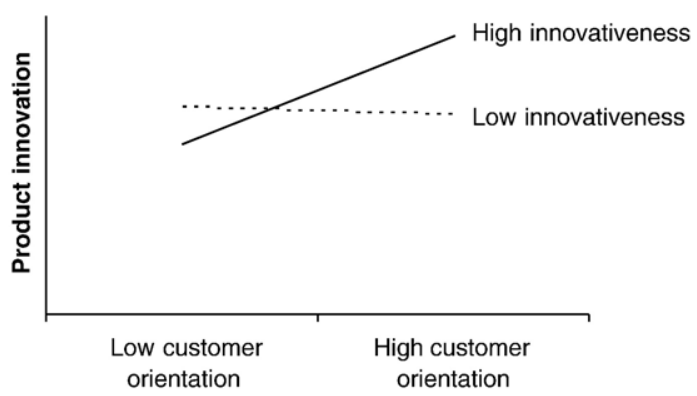

c)

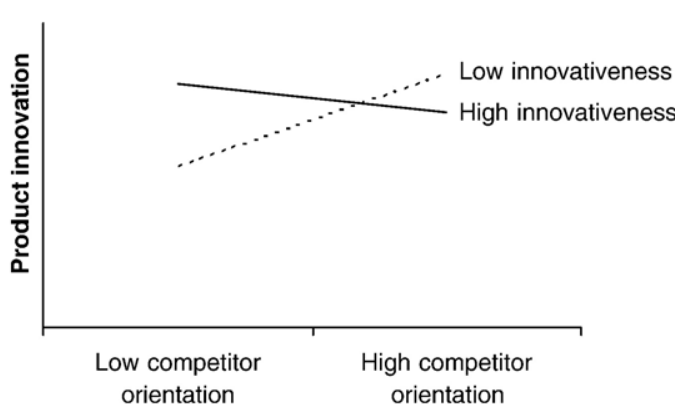

e)

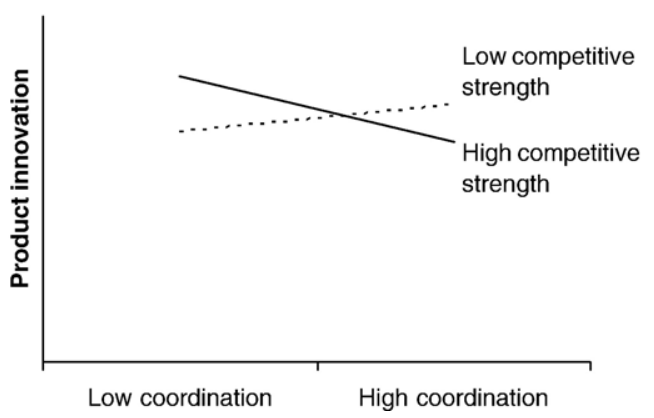

b)

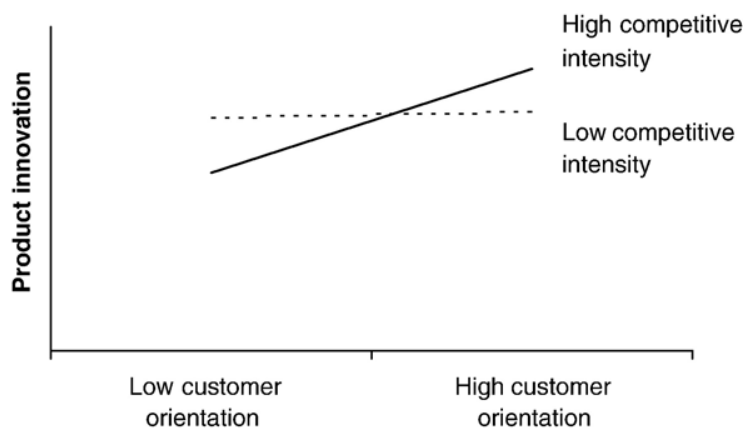

d)

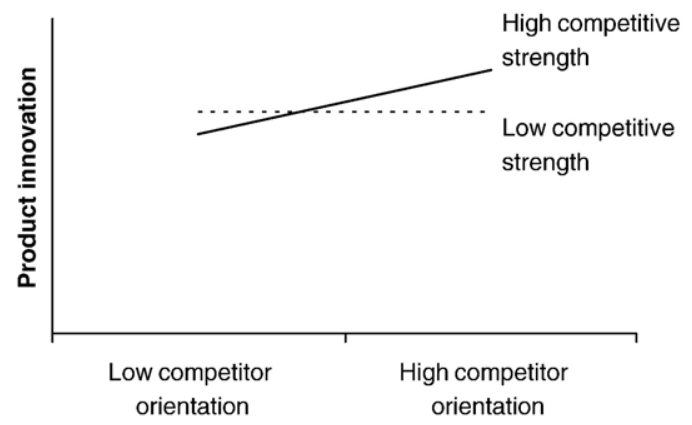

f)

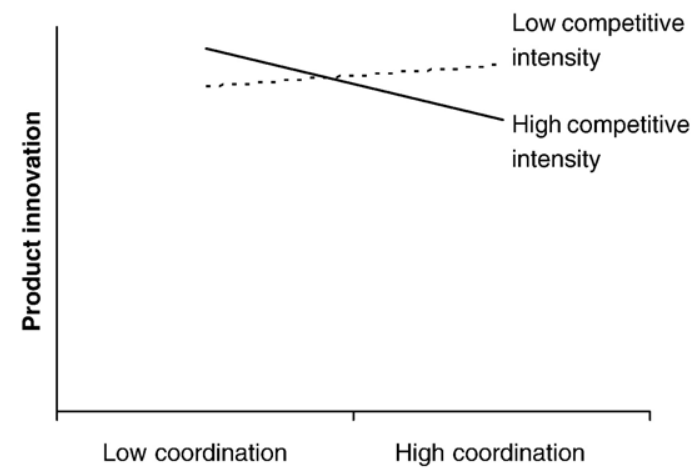

Fig. 2. Illustration of moderating effects. a) Customer orientation $\times$ Firm innovativeness. b) Customer orientation $\times$ Competitive intensity. c) Competitor orientation $\times$ Firm innovativeness d) Competitor orientation $\times$ Competitive strength. e) Interfunctional coordination $\times$ Competitive Strength. f) Interfunctional coordination $\times$ Competitive intensity.

competitive strength, and the environmental moderators. Also consistent with the overall model, we only obtained significant coefficients for customer and competitor orientation, and for technological turbulence. In summary, firm innovativeness, competitive strength, and competitive intensity appear to be pure moderators.

We subsequently discuss the findings concerning the main and the moderating effects. To facilitate interpretation of the moderating effects, we followed the procedures recommended by Aiken and West (1991) and graphically depicted the interactions (see Fig. 2). With the help of the estimated equation, the score for new-to-the-world product innovation was estimated for low and high levels of the variables involved in each interaction. Low was defined as one standard deviation below the mean, and high as one standard deviation above the mean (Aiken \& West, 1991). In estimating these scores, the effects of the other variables were kept constant at their average levels that, following the centering procedure, are zero. Then, a graph was created using the estimated scores, which were connected by lines.

\section{Discussion}

\subsection{Main effects}

Our study contributes to current literature in a number of areas. The findings extend to what is appreciated about a firm's overall performance in the field of product innovation, the idea 
that a customer orientation is important to fuel overall new-tothe-world product innovation. The conditional effect we obtained for customer orientation concurs with Lukas and Ferrell (2000). Li and Calantone (1998) also observe that customer knowledge is related with new product advantage. However, these results run against findings and arguments that customer orientation may restrain product innovativeness (e.g., Christensen, 1997; Christensen \& Bower, 1996; Gatignon \& Xuereb, 1997). The consideration of moderating effects offers a possible explanation for these mixed findings, as this study suggests that the effects of customer orientation depend upon systematic differences on other firm and market characteristics.

The main effect for competitor orientation also indicates that this orientation can be helpful for new-to-the-world product innovation, and this is consistent with $\mathrm{Li}$ and Calantone (1998), who found that competitor knowledge is associated with new product advantage. Competitor knowledge enables the identification of the total set of technologies available and under development, and also the spotting of trends in consumer behavior, and this is likely to foster new-to-the-world product innovation. Our finding, however, goes against some contentions in extant literature indicating that a competitor focus can lead to the development of me-too, rather than breakthrough, products. In fact, our finding apparently collides with that of Lukas and Ferrell (2000), who observed that competitor orientation negatively affects the introduction of new-to-theworld products. Lukas and Ferrell have only considered the three components of market orientation, whereas we have considered additional explanatory variables, and several moderating effects. Notwithstanding, our approach accommodates the finding from Lukas and Ferrell, as it shows that, under certain circumstances, competitor orientation may have a detrimental effect on product innovation (please see the section below on the moderating effects). Another possible explanation for the contradictory findings and positions in the literature concerns the level of analysis. Many studies investigate the determinants of the innovativeness of a single new product. It is possible that the innovativeness of a single product might be constrained by a focus on competitors. However, at a firm level, this knowledge may have positive effects on new-to-the-world product innovation because such knowledge may be used across different product lines to revamp product development portfolios. Finally, the results of this study suggest that a complementary explanation for the mixed positions and findings in the literature concerning competitor orientation, is that its effects are dependent on other variables.

In summary, the results associated with the main effects conform with claims that market knowledge competence is a core organizational competence (Hamel \& Prahalad, 1995; Sinkula, 1994), and that market knowledge is a strategic asset (Glazer, 1991).

Contrary to expectations, the main effect of interfunctional coordination on a firm's capacity to introduce new-to-the-world products is not significant. Other studies also provide limited evidence or no evidence at all for its impact on product innovativeness (e.g., Gatignon \& Xuereb, 1997; Lukas \& Ferrell, 2000). However, a consistent body of research has found that the integration of marketing and R\&D increases the success of new products (e.g., Atuahene-Gima \& Evangelista, 2000; Li \& Calantone, 1998; Song \& Parry, 1992). A possible explanation for the absence of a main effect is that what is particularly important is the integration between marketing and $\mathrm{R} \& \mathrm{D}$, and not integration across the board, as is conceived in the market orientation literature. As the number of departments involved in coordination increases, the negative effects of coordination, which include the compromising and homogenization of talents are likely to increase (Mukhopadhyay \& Gupta, 1998), thus reducing the extent of new-to-the-world product innovation. The current study also suggests that, an alternative explanation for the lack of a significant main effect and also to the mixed findings in the literature, is that the effects of coordination depend upon other contextual variables. Finally, the absence of a main effect for interfunctional coordination can also be attributed to the relatively low average variance extracted of this measure.

The results indicate that firm innovativeness and competitive strength are pure moderators. This contrasts with some prior studies in which firm innovativeness, in particular, is considered a mediator variable (e.g., Hult et al., 2004). Notwithstanding, our results concur with studies which considered innovativeness alongside the market orientation components (e.g., Hult \& Ketchen, 2001), and with those that obtained a rather limited role for innovativeness as a mediator (e.g., Han et al., 1998; Noble et al., 2002). Thus, our results contribute to the alternative view of innovativeness as a moderator variable.

Hurley and Hult (1998:43) considered the concept of capacity to innovate, which they defined as "the ability of the organization to adopt or to implement new ideas, processes, or products successfully", and found that the innovativeness of a group's culture positively influences the capacity to innovate. It is therefore possible that innovativeness affects product innovation through the capacity to innovate. It also seems relevant to consider the interplay between competitive strength and capacity to innovate, as Hurley and Hult (1998:45) contend that firms with "greater capacity to innovate will be more successful in responding to their environments and developing new capabilities that lead to competitive advantage and superior performance."

Technological turbulence exerts a positive main effect on product innovation, and this was unexpected. Notwithstanding, this result accords with Narver's and Slater's (1990) contention that technological changes provide more opportunities for creating value for buyers.

\subsection{Moderating effects}

We now discuss how the effects of each of the three market orientation components are affected by the moderator variables. The results indicate that the effects of customer orientation are moderated by a firm's innovativeness. In particular, Fig. 2a indicates that customer orientation on its own may not necessarily promote more innovative products. For this to happen, firms must also be innovative. In these circumstances, it seems that firms are more likely to translate into very innovative 
products, the information they obtain about customers' needs. When risk-taking and thinking outside the box are not characteristics of an organization, firms are less likely to accept the risks of betting on innovative concepts.

Furthermore, the results (see Fig. 2b) indicate that the positive impact of customer orientation on new-to-the-world product innovation is contingent upon a high level of competitive intensity. In these circumstances it becomes more important for new-to-the-world product innovation efforts to be guided by customers' needs, so that the company does not lose customers to competitors with more customer-oriented offers. When competitive intensity is low, however, a customer orientation is not that important and this opens the way for innovations to come from technical research staff and sometimes even from outside the industry (Kohli \& Jaworski, 1990), lessening the link between customer orientation and new-to-the-world product innovation.

The effects of competitor orientation are moderated by firm innovativeness and competitive strength. Somewhat surprisingly, Fig. $2 \mathrm{c}$ indicates that the positive relationship between competitor orientation and new-to-the-world product innovation only holds when firm innovativeness is low. In these circumstances, it is possible that firms may wait to see the technologies or product trends that begin to consolidate and then take the appropriate steps to capitalize on others' developments and launching costs. Fig. 2c also indicates that for higher levels of innovativeness, increases in the level of competitor orientation decrease the launch of innovative products. It is possible that innovativeness, which promotes breakthrough ideas, together with strong competitor knowledge, may originate the identification of contradictory new product development paths, causing the company to become uncertain about the way to proceed, and this may mitigate the development of new-to-the-world products. Finally, and according to Fig. 2d, the positive implications of competitor knowledge seem to materialize particularly for highly competitive organizations, which are probably more experienced at using competitor information to their advantage.

The results also indicate that the effects of coordination are contingent upon other variables. In Fig. 2e we observe that when competitive strength is high, the relationship between interfunctional coordination and new-to-the-world product innovation becomes negative. This finding can probably be attributed to the fact that the development and maintenance of competitive strength resides in the implementation of some bold decisions, and this may collide with coordination across the board, ending up damaging the probability of a firm being first to market with innovative products. A contemporary example of this potential side effect of coordination relates to the announcement by Sony's recently-elected CEO, Howard Stringer, that the company's new strategy did not consider American-style business rationalization to be possible in the 'consensus world' of Japan, leading the firm's stock to an immediate $6 \%$ fall (Anonymous, 2005). The positive effects of coordination emerge when firms have a low degree of competitive strength. In such circumstances, it is possible that these organizations use their collective knowledge to produce some breakthrough products.
Fig. $2 \mathrm{f}$ further indicates that when competitive intensity is high, increases in coordination are detrimental to the development of new-to-the-world products. As with competitive strength, it is likely that competitive environments require fast and bold decisions, and the consensus style associated with coordination may preclude this, delaying the development of products and reducing the likelihood of being first to market. When competitive intensity is low, firms are less likely to become overtaken by competitors' product moves, and this enables coordination to exert its positive effects on new-to-theworld product innovation.

Finally, several hypotheses concerning moderating effects did not receive support. The sample size is not that large, and this may have had the effect of revealing only the strongest influences. With regard to the moderating effects of the environment, other research (e.g., Gatignon \& Xuereb, 1997; Li \& Calantone, 1998) has also observed a mixed pattern of findings. Such a pattern can possibly be explained by industry differences in the flow of new product launches and also in terms of sensitivity to environmental conditions. In a meta-analytic study, Kirca, Jayachandran, and Bearden (2005) also did not find evidence for the moderating role of several environmental moderators on the relationship between market orientation and firm performance.

In summary, this study contributes to the literature in different ways. Firstly, it enriches the product development literature by shedding light on the determinants of a firm's overall new-to-the-world product innovation, which has scarcely been considered in extant research. Secondly, it clarifies the debate over how the market orientation components affect the development of innovative products. Our study highlights that these effects are moderated by firm innovativeness and competitive strength, the effects of which have been neglected in previous research, and also by environmental forces. The moderating effects we have thus considered may, at least in part, clarify some contradictory findings in the literature, as they indicate that the effects of the market orientation components are contingent upon the influence of other variables, some of which had not previously been explored.

\section{Managerial implications}

Our study provides some guidelines for managers involved in new product development. First of all, the results associated with the conditional effects of customer and competitor orientation indicate that the commitment to, and implementation of, the activities associated with the collection and dissemination of customer and competitor information, seem to enable the organization to better explore market trends through the development of new-to-the-world products. Consequently, the results provide some support to viewing market sensing as a distinctive capability (Day, 1994) that should be properly considered by managers. However, the consequences associated with this market information may not apply equally to all companies, as discussed below.

The findings pertaining to interfunctional coordination should be considered with caution, as the positive effects of 
integration, particularly between $\mathrm{R} \& \mathrm{D}$ and marketing, are well documented in the literature. Therefore, it would be inappropriate to discard the role of integration. Thus, managers should closely analyze the integration mechanisms, the number of units involved in new product development, and also the negative effects that can be associated with attempts to coordinate, and that include conflicts and compromises.

Our results also indicate that managers should build a market orientation along with an organizational culture that values innovation. Although firm innovativeness may not contribute directly to the introduction of new products, it helps in creating an internal environment that fosters the exploration of customer information in more novel ways. However, managers must consider that when innovativeness is high, being too competitor-focused may eventually create uncertainties concerning the research directions to follow, and managers must safeguard against these outcomes.

Managers should also be aware that as the level of competitive strength increases, firms are more likely to benefit from the competitor intelligence they gather, increasing the development and launching of truly innovative products. However, competitive strength seems to mitigate the positive and reinforce the negative effects of interfunctional coordination. Thus, organizations must be aware of these negative side effects and, possibly, strive to maintain their ability to take the bold product decisions that are required to sustain their competitive strength in the long term.

Finally, managers must consider that the pay-offs associated with market orientation are influenced by the environment, and this appreciation can be useful in calibrating resource allocation. In particular, it seems that the rewards of customer orientation increase with the level of competitive intensity. Consequently, managers should divert more of their attention and resources to the analysis of customer needs in environments marked by fierce competition. Furthermore, our results suggest that the positive effects of coordination are attenuated while the negative effects are strengthened in competitive environments, and this suggests that managers should possibly relinquish some coordination in these environments.

\section{Conclusions and directions for future research}

This study suffers from a number of shortcomings that must be considered and possibly addressed in future research. The sample is composed of a diverse number of industries. This approach promotes the generalization of results. However, it has been found that sometimes the results are industry-sensitive. Consequently, it would be interesting to investigate whether the findings in this study are replicated in specific industries. We also did not test the relationship between firm performance and overall new-to-the-world product innovation. This would have provided further evidence on the importance of our dependent variable. In addition, some of the variables in our study have an average variance extracted below 0.50 , and this may have affected the capacity to detect significant relationships. The sample size also is not that large, particularly considering the number of variables in the study, and this adversely affects the power to detect significant relationships. Consequently, this may be an additional explanation for not finding significant effects for some of the predictors.

Building a market orientation is considered a long-term endeavor that does not necessarily produce immediate pay-offs. This implies the suitability of a longitudinal study. However, the findings in our study are obtained from cross-sectional data. We also rested on Narver's and Slater's (1990) conceptualization of market orientation, but other conceptualizations have been developed (e.g., Deshpandé et al., 1993; Kohli \& Jaworski, 1990). Consequently, future research may investigate the effects of different operationalizations of market orientation on new product development.

The literature reveals conflicting results involving the different components of market orientation. Kohli and Jaworski (1990:16) suggest that simply implementing market-oriented activities does not necessarily ensure the quality of those activities. It is thus urgent to consider whether the quality of the market-oriented activities is interfering in the relationship between market orientation, new product development, and organizational performance. This research would be well positioned to make a significant contribution to theory. It is also possible that other variables moderate, and even mediate, the relationship between market orientation and product innovation, and this deserves consideration. Technological orientation, defined as the "ability and will to acquire a substantial technological background and use it in the development of new products" (Gatignon \& Xuereb, 1997: 78) has the potential to moderate the effects of the market orientation components on the development of highly innovative products. It seems plausible as well to envisage the moderating or mediating effect of the quality of market-oriented activities on the relationship between market orientation and product innovation.

This study did not find a significant link between innovativeness, competitive strength and new-to-the-world product innovation. In line with the previous discussion, future research should address the interplay of these variables with technological orientation to affect product innovation. Furthermore, innovativeness has been considered either a consequence of market orientation (e.g., Hult et al., 2004), or an orientation that may co-exist alongside market orientation (e.g., Hult \& Ketchen, 2001), and this seems to be an issue deserving future clarification.

Research in this area can also further explore the role of coordination in new product development. The literature is plagued with contradictory findings concerning the effects of interfunctional coordination. We therefore believe that it is relevant to research whether it is firm-wise coordination or solely the integration of marketing and R\&D that matters most for the development of new products. Related to this issue, is the analysis of the consequences, namely in terms of degree of innovation, entry timing, and the planning of activities, associated with an increase in the number of departments 
involved in the coordination of new product development. We speculate that an increase in the number of departments involved will produce mixed consequences. Furthermore, coordination has been associated with some drawbacks, namely conflicts of interest between different departments and compromising solutions, and these can possibly explain some of the conflicting results in the literature. Consequently, investigating the extent to which these drawbacks take place can have significant pay-offs.

\section{Appendix A}

Survey items, standardized loadings, and t-values

Standardized $t$-values loadings

Model 1

Customer orientation

We assess regularly the satisfaction of our customers

The accomplishment of our goals is based

on the satisfaction of our customers

We regularly monitor and assess our commitment to customer satisfaction*

We provide a great deal of attention to after-sales service

We continuously seek to increase the value we provide to our customers

Our competitive advantage is based on understanding our customers' needs

\section{Competitor orientation}

In our organization salespeople share competitor information

We respond quickly to competitors' strategies

We try to identify and target opportunities before competitors

Top managers discuss the strengths and weaknesses of competitors

Interfunctional coordination

Department heads regularly visit and talk to our main customers

All functions/departments are integrated to satisfy customers' needs

Top managers recognize that that everybody in the organization is important to create value for customers

Information about current and potential competitors is distributed organization-wide

\section{Model 2}

\section{Technological turbulence}

The technology in our industry is changing rapidly

Technological changes provide big opportunities in our industry

A large number of new product ideas have been made possible through technological breakthroughs in our industry

Technological developments in our industry are rather minor (rev)

\section{Competitive intensity}

Competition in our industry is cut-throat

There are many 'promotion wars' in our industry

Anything that one competitor can offer, others can match readily

Price competition is a hallmark of our industry
Appendix A (continued)

Standardized $t$-values loadings

Model 3

Firm innovativeness

Technical innovation, based on research results, $\quad .80$ is readily accepted

Management actively seeks innovative ideas $\quad .67$

New ideas are rapidly accepted in this organization $\quad .77$

Competitive strength

Level of firm's prices

Quality of products

Capacity to win market share

Diversity of products

(in products, ...) $\quad .83$

New-to-the-World Product Innovation

Number of completely new products (products $\quad .84$ new to your company and new to your market) launched in the market

Degree of innovativeness of the products launched .82 in the market

* This item was eliminated during confirmatory factor analysis.

\section{References}

Achrol, R., \& Stern, L. (1988). Environmental determinants of decision-making uncertainty in marketing channels. Journal of Marketing Research, 25(1), 36-50.

Aiken, M., \& Hage, J. (1971). The organic organization and innovation. Sociology, 5(1), 63-82.

Aiken, L. S., \& West, S. G. (1991). Multiple regression: testing and interpreting interactions. London: Sage.

Aldrich, H. E. (1979). Organisations and environments. Englewood Cliffs: Prentice-Hall

Anderson, E., Day, G. S., \& Rangan, V. K. (1997). Strategic channel design. Sloan Management Review, 38(4), 59-69.

Anonymous. (2005, October 1). Stringing along. The Economist, 58.

Anonymous. (2006a, October 7). The cutting edge. The Economist, 74.

Anonymous. (2006b, September 30). Terry Semel's long pause. The Economist, 69.

Atuahene-Gima, K. (1996). Market orientation and innovation. Journal of Business Research, 35(2), 93-103.

Atuahene-Gima, K., \& Evangelista, F. (2000). Cross-functional influence in new product development: An exploratory study of R\&D and marketing perspectives. Management Science, 46(10), 1269-1284.

Atuahene-Gima, K., Li, H., \& De Luca, L. M. (2006). The contingent value of marketing strategy innovativeness for product development performance in Chinese new technology ventures. Industrial Marketing Management, 35 (3), 359-372.

Auh, S., \& Menguc, B. (2005). Top management team diversity and innovativeness: The moderating role of interfunctional coordination. Industrial Marketing Management, 34(3), 249-261.

Baker, W. E., \& Sinkula, J. M. (1999). The synergistic effect of market orientation and learning orientation on organizational performance. Journal of Academy of Marketing Science, 27(4), 414-427.

Barney, J. B. (1991). Firm resources and sustained competitive advantage. Journal of Management, 17(94), 99-120.

Bennett, R. C., \& Cooper, R. G. (1981). Beyond the marketing concept. Business Horizons, 22(3), 76-83.

Booz, Allen \& Hamilton Inc. (1982). New product management for the 1980's. New York: Booz, Allen, \& Hamilton, Inc.

Burke, M. C. (1984). Strategic choice and marketing managers: An examination of business-level marketing objectives. Journal of Marketing Research, 21 (4), 345-359.

Christensen, C. M. (1997). The innovator's dilemma. Boston: Harvard Business School Press. 
Christensen, C. M., \& Bower, J. L. (1996). Customer power, strategic investment, and the failure of leading firms. Strategic Management Journal, 17(3), 197-218.

Damanpour, F. (1991). Organizational innovation: a meta analysis of effects of determinants and moderators. Academy of Management Journal, 34(3), 555-590.

Damanpour, F., Szabat, K. A., \& Evan, W. M. (1989). The relationship between types of innovation and organizational performance. Journal of Management Studies, 26(6), 587-601.

Day, G. S. (1994). The capabilities of market-driven organizations. Journal of Marketing, 58(4), 37-52.

Day, G. S., \& Wensley, R. (1988). Assessing advantage: A framework for diagnosing competitive superiority. Journal of Marketing, 52(2), 1-20.

Deshpandé, R., Farley, J. U., \& Webster, F. E., Jr. (1993). Corporate culture, customer orientation, and innovativeness in Japanese firms: A quadrad analysis. Journal of Marketing, 57(1), 23-37.

Dickson, P. R. (1992). Toward a general theory of competitive rationality. Journal of Marketing, 56(1), 69-83.

Fornell, C., \& Larcker, D. F. (1981, February). Evaluating structural equation models with unobservable variables and measurement error. Journal of Marketing Research, 18, 39-50.

Garcia, R., \& Calantone, R. (2002). A critical look at technological innovation typology and innovativeness terminology: A literature review. Journal of Product Innovation Management, 19, 110-132.

Gatignon, H., \& Robertson, T. S. (1989). Technology diffusion: an empirical test of competitive effect. Journal of Marketing, 53(1), 35-49.

Gatignon, H., \& Xuereb, J. -M. (1997). Strategic orientation of the firm and new product performance. Journal of Marketing Research, 34(1), 77-90.

Ginsberg, A., \& Venkatraman, N. (1985). Contingency perspectives of organizational strategy: A critical review of the empirical research. Acad emy of Management Review, 10(3), 421-434.

Glazer, R. (1991, October). Marketing in an information-intensive environment: Strategic implications of knowledge as an asset. Journal of Marketing, 55, 1-19.

Hair, J. F., Anderson, R. E., Tatham, R. L., \& Black, W. C. (1998). Multivariate Data Analysis, (5th ed.). London: Prentice-Hall.

Hamel, G., \& Prahalad, C. K. (1995). Strategic intent. In H. Mintzberg, J. B. Quinn, \& S. Ghoshal (Eds.), The Strategy Process, European Edition (pp. 34-40). London: Prentice Hall.

Han, J. K., Kim, N., \& Srivastava, R. K. (1998). Market orientation and organizational performance: Is innovation a missing link? Journal of Marketing, 62(4), 30-45.

Hatcher, L. (1994). A set-by-step approach to using the sas system for factor analysis and structural equation modeling. Cary: NC: SAS Institute.

Hayes, R. H., \& Abernathy, W. J. (1980). Managing our way to economic decline. Harvard Business Review, 58(4), 67-77.

Hult, G. T., Hurley, R. F., \& Knight, G. A. (2004). Innovativeness: Its antecedents and impact on business performance. Industrial Marketing Management, 33(5), 429-438.

Hult, G. T. M., \& Ketchen, D. J. (2001). Does market orientation matter? A test of the relationship between positional advantage and performance. Strategic Management Journal, 22(9), 899-906.

Hult, G. T., Ketchen, D. J., \& Nichols, E. L. (2002). An examination of cultural competitiveness and order fulfillment cycle time within supply chains. Academy of Management Journal, 45(3), 577-585.

Hurley, R. F., \& Hult, G. T. M. (1998). Innovation, market orientation, and firm learning: an integration and empirical examination. Journal of Marketing, $62(3), 42-54$

Jaworski, B., \& Kohli, A. (1993). Market orientation: Antecedents and consequences. Journal of Marketing, 57(3), 53-70.

Jaworski, B., \& Kohli, A. (1996). Market orientation: Review, refinement, and roadmap. Journal of Market Focused Management, 1(2), 119-135.

Kirca, A. H., Jayachandran, S., \& Bearden, W. O. (2005). Market orientation: A meta-analytic review and assessment of its antecedents and impact on performance. Journal of Marketing, 69(April), 24-41.

Kleinbaum, D. G. (1994). Logistic regression: A self learning text. London: Springer.

Kohli, A., \& Jaworski, B. J. (1990). Market orientation: the construct, research propositions, and managerial implications. Journal of Marketing, 54(2), 1-18.
Li, T., \& Calantone, R. J. (1998). The impact of market knowledge competence on new product advantage: Conceptualization and empirical examination. Journal of Marketing, 62(4), 13-29.

Lukas, B. A., \& Ferrell, O. C. (2000). The effect of market orientation on product innovation. Journal of the Academy of Marketing Sciences, 28(2), 239-247.

Menon, A., \& Varadarajan, P. R. (1992). A model of marketing knowledge use within firms. Journal of Marketing, 56(4), 53-71.

Mukhopadhyay, S. K., \& Gupta, A. V. (1998). Interfaces for resolving marketing, manufacturing and design conflicts: A conceptual framework. European Journal of Marketing, 32(1/2), 101-124.

Narver, J., \& Slater, S. (1990). The effect of a market orientation on business profitability. Journal of Marketing, 54(4), 20-35.

Noble, C. H., Sinha, R. K., \& Kumar, A. (2002). Market orientation and alternative strategic orientations: A longitudinal assessment of performance implications. Journal of Marketing, 66(4), 25-39.

Olson, E. M., Walker, O. C., \& Ruekert, R. W. (1995). Organizing for effective new product development: The moderating role of product innovativeness. Journal of Marketing, 59(1), 48-62.

Pfeffer, J., \& Salancik, G. R. (1978). The external control of organisations: A resource dependence perspective. London: Harper and Row.

Robinson, W. T., \& Min, S. (2002, February). Is the first to market to market the first to fail? Empirical evidence for industrial goods businesses. Journal of Marketing Research, 29, 120-128.

Shamsie, J., Phelps, C., \& Kuperman, J. (2004). Better later than never: A study of late entrants in household electrical equipment. Strategic Management Journal, 25(1), 69-94.

Sharma, S., Durand, R. M., \& Gur-Arie, O. (1981). Identification and analysis of moderator variables. Journal of Marketing Research, 18(3), 291-300.

Sinkula, J. M. (1994). Market information processing and organizational learning. Journal of Marketing, 58(1), 35-45.

Slater, S., \& Narver, J. C. (1994). Does competitive environment moderate the market orientation-performance relationship? Journal of Marketing, 58(1), 46-55.

Slater, S. F., \& Narver, J. C. (1995). Market orientation and the learning organization. Journal of Marketing, 59(3), 63-74.

Slater, S. F., \& Narver, J. C. (1998). Customer-led and market-oriented: Let's not confuse the two. Strategic Management Journal, 19(10), 1001-1006.

Slater, S. F., \& Narver, J. C. (1999). Market-oriented is more than being customer-led. Strategic Management Journal, 20(12), 1165-1168.

Song, X. M., \& Parry, M. E. (1992). The R\&D - marketing interface in Japanese high-technology firms. Journal of Product Innovation Management, 9(2), 91-112.

Szymanski, D. M., Troy, L. C., \& Bharadwaj, S. G. (1995). Order of entry and business performance: An empirical synthesis and reexamination. Journal of Marketing, 59(4), 17-33.

Tate, R. L. (1984). Limitations of centering for interactive models. Sociological Methods \& Research, 13(2), 251-271.

Voss, G. B., \& Voss, Z. G. (2000). Strategic orientation and firm performance in an artistic environment. Journal of Marketing, 64(1), 67-83.

Wheelwright, S. C., \& Clark, K. B. (1992). Creating project plans to focus product development. Harvard Business Review, 70(2), 10-82.

Wind, J., \& Mahajan, V. (1997). Issues and opportunities in new product development: An introduction to the special issue. Journal of Marketing Research, 34(1), 1-12.

Zahra, S. A., Nash, S., \& Brickford, D. J. (1995). Transforming technological pioneering into competitive advantage. Academy of Management Executive, 9(1), 17-31.

Zhou, K. Z. (2006). Innovation, imitation, and new product performance: The case of China. Industrial Marketing Management, 35(3), 394-402.

Zhou, K. Z., Yim, C. K., \& Tse, D. K. (2005). The effects of strategic orientations on technology and market-based breakthrough innovations. Journal of Marketing, 69(2), 42-60

Mário Augusto is an assistant professor and his research interests are in the field of finance, firm performance, and in the interface between finance and marketing.

Filipe Coelho is an assistant professor and his research interests include market orientation, distribution strategy, and the behaviour of frontline employees. 